\title{
Debt Restructuring with Multiple Creditors and the Role of Exchange Offers*
}

\author{
Enrica Detragiache \\ Research Department, International Monetary Fund, Washington, DC, 20431 \\ AND \\ Paolo G. Garella \\ Dipartimento di Economia, Universita' di Bologna, Bologna, Italy \\ Received April 27, 1995

\begin{abstract}
Exploiting the analogy with the private provision of a public good, this paper studies debt restructuring with an arbitrary number of creditors using mechanism design. Creditors differ in the value they expect to receive in bankruptcy, and this value is private information. As with public goods, too little debt forgiveness is granted in equilibrium relative to the first best. Creditors are more willing to make concessions under common values than under pure private values, an opposite phenomenon to the "winners' curse" in auctions. Exchange offers are an optimal restructuring scheme for the debtor, because they allow creditors to contribute to debt forgiveness at different levels. Journal of Economic Literature Classification Numbers: G34, G33. (c) 1996 Academic Press, Inc.
\end{abstract}

\section{INTRODUCTION}

An important issue in the theory of corporate finance is the nature of the costs of financial distress. While there are no costs of financial distress if debt contracts can be efficiently renegotiated (Haugen and Senbet, 1978), in practice debt renegotiation is often difficult. Granting sufficient debt

\footnotetext{
* We thank workshop participants at IGIER, Rutgers University, and the Federal Reserve Bank of Richmond for very helpful comments and discussions. Most of this research was conducted while E. Detragiache was at Johns Hopkins University. The views expressed in the paper are those of the authors and do not necessarily represent those of the institutions to which they belong.
} 
forgiveness to an insolvent firm requires a high degree of coordination among creditors, and coordination is difficult to achieve when creditors are many. A number of authors have suggested that the larger the number of creditors the more difficult is debt renegotiation (Bulow and Shoven, 1978; White, 1980 and 1989), and empirical evidence shows that firms with more layers of creditors are less likely to restructure their debts out of court (Gilson et al., 1990). The concern about losses of firm value in financial distress has led a number of countries to introduce special bankruptcy statutes which, by weakening creditors' contractual rights, make it easier for indebted firms to obtain debt forgiveness (Mitchell, 1990). Various authors have identified the existence of coordination problems among multiple creditors as the main economic rationale for such statutes (see for instance Jackson, 1986, and Webb, 1991). ${ }^{1}$ Also, the assumption that widely held debt cannot be renegotiated while privately held debt can has been recently used to explain why companies use both types of financial instruments (Detragiache, 1994; Hart and Moore, 1995; Bolton and Scharfstein, 1996).

In practice, even if they have multiple creditors, firms often succeed in restructuring their debt out of court through exchange offers. ${ }^{2}$ In an exchange offer, bondholders are offered to trade their old claims for a new security, such as a bond with lower face value or a mix of debt and equity; bondholders are free to exchange any fraction of their portfolio. The success of the offer is usually conditional on a minimum tendering requirement announced before tendering begins.

In this paper we develop a model of debt renegotiation with an arbitrary number of privately informed creditors designed to answer a normative and a positive question: the normative question is whether it is possible, given creditors' prebankruptcy contractual rights, to devise a debt renegotiation mechanism that is ex post efficient, i.e., that ensures that no going concern value is lost. In other words, we ask whether the common view that out-of-court renegotiation tends to yield too little debt forgiveness is borne out, once a fairly general model of renegotiation is analyzed. The positive question is why exchange offers are so widespread a device for debt renegotiation.

To construct an analytical framework for this inquiry, we exploit the analogy between debt renegotiation and the classic economic problem of financing the production of a public good through private contributions. If

\footnotetext{
${ }^{1}$ Debt renegotiation may also be inefficient when the indebted firm has private information about its going concern value. On this subject, see Giammarino (1989), Webb (1987), and Detragiache (1995).

${ }^{2}$ For empirical evidence on exchange offers and corporate debt workouts, see Weiss (1990), Gilson et al. (1990), Asquith et al. (1994), and Altman (1993).
} 
the indebted firm is viable, debt renegotiation can benefit the creditors (it can keep the firm in business, creating more value to be divided among claimholders). However, the benefit is nonexcludable, because creditors who refuse to write down their claims cannot be prevented from receiving a higher repayment rate if the firm remains in business. So the increase in the value of the firm due to debt renegotiation is a public good for the creditors. Using mechanism design, Laffont and Maskin (1979), Rob (1989), and Mailath and Postlewaite (1990) study whether the production of a public good can be efficient when it must be financed through voluntary contributions from consumers, and consumers are privately informed about their willingness to pay. Their results can be directly applied to debt renegotiation.

In our model, debt forgiveness can increase the value of the firm because it improves investment incentives (Myers, 1977). ${ }^{3}$ There is an arbitrary but finite number of creditors. Creditors differ in the utility that they expect to receive in case of bankruptcy. Creditor heterogeneity stems from differences in preferences and/or differences in the information used to forecast the bankruptcy value of the firm. In the language of auction theory, if creditors differ only because of different preferences the model is one of private values. If creditors have also different information, the model is one of common values, and the expected bankruptcy payoff of a creditor is affected by the private information that other creditors may reveal through their actions. ${ }^{4}$

As with public goods, it can be easily shown that all renegotiation mechanisms yield less debt forgiveness than would be ex post efficient. Thus, our results support the argument that financial distress is more costly when there is a large number of creditors. The reason is the standard free-rider problem. Inducing creditors to reveal their true willingness to contribute to debt forgiveness is costly, and, since creditors' participation is voluntary, the cost are borne by the shareholders of the indebted firm. Even if the going concern value of the firm exceeds its value in bankruptcy, the costs of debt restructuring to shareholders may exceed the benefits, and debt renegotiation may fail. This result depends crucially on the assumption that creditors have private information. Since creditors are not atomistic, with full information a renegotiation plan could be devised to make each creditor pivotal, thereby implementing the ex post efficient outcome as in the takeover model of Bagnoli and Lipman (1988). We believe that the private nature of creditors' informa-

${ }^{3}$ When a company has a large debt outstanding, creditors appropriate some of the returns from new investment, so shareholder-oriented management invests too little.

${ }^{4}$ The work on public goods cited above is restricted to the pure private values case. 
tion about their willingness to pay is an important feature of real-world debt workouts.

A second result is that creditors can be more easily coordinated when they have common values. The intuition is the following. Each creditor knows that a restructuring plan succeeds only if other creditors are also willing to make concessions. But if other creditors are willing to write down their claims, then they must have information that the bankruptcy value of the firm is low. Such knowledge makes creditors more willing to offer debt forgiveness. This is the opposite of the well-known "winners' curse" phenomenon in auctions: with common values, bidders bid less aggressively because winning conveys unfavorable information about the true value of the object (see, for instance, Milgrom, 1987).

In the second part of the analysis, it is shown that exchange offers allow the debtor to maximize expected profits from renegotiation. Since it is natural to assume that the renegotiation scheme is chosen by the debtor, this result explains why exchange offers are so popular. In contrast with other restructuring mechanisms, exchange offers allow the debtor to engage in a form of "price discrimination": by choosing to exchange a different fraction of their loan portfolio, creditors contribute to debt forgiveness at different levels, and the debtor can take advantage of their different willingness to pay. Predictably, creditors who expect a high payoff in bankruptcy choose to tender a small fraction of their claims, and vice versa. The probability of success of the offer is increasing in the going concern value of the firm.

Exchange offers are also studied by Gertner and Scharfstein (1991). These authors model bondholders as homogeneous and atomistic, and find that exchange offers succeed only if the new claims have a higher priority status (or shorter maturity) than the old ones. Otherwise, all bondholders hold out, and the offer fails regardless of the magnitude of the welfare gain from debt forgiveness. In practice, however, successful debt restructurings involving exchanges of debt of similar maturity and priority have been observed empirically (Asquith et al., 1994). Our results indicate that, if creditors are not atomistic, so that their decisions have a nonnegligible effect on the probability of success of renegotiation, then exchange offers involving lower priority debt succeed with positive probability, although less often than it would be socially efficient.

The paper is organized as follows. Section 2 contains the basic model and the main results about the efficiency of debt renegotiation. Section 3 shows the optimality of exchange offers. In Section 4 we discuss the implications of letting creditors trade in the distressed securities. Section 5 explores the issue of resolving financial distress by obtaining permission from the creditors to issue senior debt. Some extensions and open issues are discussed in Section 6, and Section 7 concludes. 


\section{A MODEL OF DEBT RESTRUCTURING}

\subsection{The Basic Setup}

A firm has a project that requires an investment of $I$ in the current period, and yields future cash flows with present discounted value of $C+I$ (with $C>0$ ). The project is lost if the firm files for bankruptcy. The firm has a total debt outstanding of $D$ and no cash in hand, so it needs external funds to finance both investment and debt service. If the firm is allowed to issue new claims senior to existing debt, then financing should be forthcoming, because $C>0$. However, if outstanding debt has protective covenants forbidding the issuance of senior debt, then a new loan is profitable if and only if

$$
(C+I)-D-I=C-D>0 .
$$

In the rest of the paper, it will be assumed that this inequality fails and that the issuance of higher priority debt is prohibited by existing covenants, so that the firm can avoid bankruptcy and take advantage of the investment project only if it obtains sufficient debt forgiveness. ${ }^{5}$ This is just a version of the underinvestment problem identified by Myers (1977). Thus, management undertakes negotiations with the creditors to arrive at a "debt workout" agreement by which creditors write down some of the interest rate and/or the principal of their loans. Since debt is renegotiated outside of bankruptcy, creditors must offer debt reduction voluntarily. Loan contracts do not specify procedures for renegotiation outside of bankruptcy, so the parties are free to adopt any procedure that they like. ${ }^{6}$

It is assumed that the debt outstanding is in the hands of $n$ creditors who are risk-neutral and have equal priority. For simplicity, creditors hold identical shares $d=D / n$ of total debt outstanding. Each creditor knows that if some debt is not written down the firm has to forgo the investment project, and his willingness to offer debt forgiveness depends on two factors: the payoff that he expects to receive if the firm does not invest and goes bankrupt, and his assessment as to how much debt forgiveness will be provided by the other creditors. $x_{i}$ denotes the payoff that creditor $i$ expects to receive in bankruptcy. We will assume that $x_{i}$ is private information and that all other creditors (and the debtor) have identical beliefs as to the

\footnotetext{
${ }^{5}$ The possibility of renegotiating the seniority covenant instead of renegotiating the face value of the debt is discussed in Section 4 below.

${ }^{6}$ Our analysis does not address the issue of how to design optimal renegotiation provisions to include in debt contracts. Rather, we take contractual incompleteness as given, and study what outcomes can be achieved through renegotiation.
} 
possible value of $x_{i} \cdot{ }^{7}$ These beliefs are captured by the random variable $X_{i}:[\underline{x}, \bar{x}] \rightarrow[0,1]$ that has distribution $F\left(x_{i}\right)$ and density $f\left(x_{i}\right) . x_{i}$ will be referred to as the "type" of creditor $i$. The vector $x \equiv\left(x_{1}, \ldots, x_{n}\right)$ denotes a realization of creditor types, while $I_{k} \equiv\left\{x \mid \underline{x} \leq x_{j} \leq \bar{x}\right.$ for $j=1,2, \ldots$, $k$ \} (with $k=1,2, \ldots, n$ ) is the set of all possible types of $k$ creditors. Creditor types are assumed to be identically and independently distributed. ${ }^{8}$ In the rest of the paper, the following definitions will be used:

$$
\begin{aligned}
f(x) & \equiv \prod_{j=1}^{n} f\left(x_{j}\right) \\
x_{-i} & \equiv\left(x_{1}, \ldots, x_{i-1}, x_{i+1}, \ldots, x_{n}\right) \\
f\left(x_{-i}\right) & \equiv \prod_{j \neq i} f\left(x_{j}\right) .
\end{aligned}
$$

Different values of $x_{i}$ across creditors may arise because creditors have different preferences. For instance, tax considerations and regulatory constraints may make bankruptcy more or less attractive to different investors. ${ }^{9}$ In this case, the model would be one of pure private values. If creditors also have different information about the outcome of bankruptcy, then the model is one of common values and the private information received by creditor $i$ can help other creditors improve their forecast of their bankruptcy payoff. Following Myerson (1981), if creditor $i$ knew the payoff expected by other creditors, his revised expected payoff in bankruptcy would be

$$
l_{i}\left(x_{i}, x_{-i}\right) \equiv x_{i}+\sum_{j \neq i} e_{i}\left(x_{j}\right)
$$

where the revision functions $e_{i}:[\underline{x}, \bar{x}] \rightarrow \mathbb{R}$ are nondecreasing, and satisfy

$$
\int_{\underline{x}}^{\bar{x}} e_{i}\left(x_{j}\right) f\left(x_{j}\right) d x_{j}=0
$$

for all $j \neq i$. This property of the revision functions implies

$$
\int_{I_{n-1}} l_{i}\left(x_{i}, x_{-i}\right) f\left(x_{-i}\right) d x_{-i}=x_{i},
$$

${ }^{7}$ The debtor may also have private information about the bankruptcy value of the firm. See Section 6 below for a discussion of this possibility.

${ }^{8}$ On mechanism design when private information is correlated see Crémer and McLean (1988).

${ }^{9}$ For instance, debt forgiveness may be more attractive to bank creditors who are poorly capitalized and/or already have large tax credits from loss carry-forwards, because it can often be designed to avoid explicit debt write-offs. 
so we will continue to refer to $x_{i}$ as the expected bankruptcy value of creditor $i$. The common values model can be easily given a pure private values interpretation by letting the revision functions be identically equal to zero.

Definition. The model is one of pure private values if $e_{i}\left(x_{j}\right)=0$ for all possible values of $i, j$, and $x_{j}$. This implies $l_{i}\left(x_{i}, x_{-i}\right)=x_{i} \forall x_{-i} \in I_{n-1}$.

To simplify the notation, define

$$
e_{i}\left(x_{-i}\right) \equiv \sum_{j \neq i} e_{i}\left(x_{j}\right)
$$

For the sake of realism, it is assumed that the payoff that creditors expect to receive in bankruptcy does not exceed the full face value of the debt.

Assumption 1. $l_{i}\left(x_{i}, x_{-i}\right) \leq d$ for all $x_{i} \in[\underline{x}, \bar{x}], x_{-i} \in I_{n-1}$, and $i=$ $1, \ldots, n$.

The quantity $C-\sum_{i=1}^{n} l_{i}\left(x_{i}, x_{-i}\right)$ is the difference between the value of the firm as a going concern and the value of the firm in bankruptcy, i.e., it is the "going concern surplus." In a recent paper, Alderson and Betker (1995) develop a technique to estimate the going concern surplus of a sample of U.S. firms that reorganized in Chapter 11, and find that for $80 \%$ of these firms the surplus was positive, so that debt restructuring was efficient. The next definition makes explicit the notion of efficient debt renegotiation in the context of our model.

Definition. Debt restructuring satisfies ex post efficiency if and only if the new investment project is undertaken (and the firm remains in business) with probability one when

$$
C \geq \sum_{i=1}^{n} l_{i}\left(x_{i}, x_{-i}\right)
$$

and the project is undertaken with probability zero (and the firm goes bankrupt) otherwise.

\subsection{The Revelation Game}

To answer the normative question of whether ex post efficiency can be obtained through debt renegotiation, we adopt a mechanism design approach similar to that used by Laffont and Maskin (1979), Rob (1989), and Mailath and Postlewaite (1990) to study the private provision of a public good. Specifically, we ask whether there exists a procedure (a mechanism) for renegotiating the debt that yields an ex post efficient equilibrium out- 
come. We limit our investigation to a special class of mechanisms called revelation mechanisms, because by the Revelation Principle (Myerson, 1981) all equilibrium outcomes of all possible mechanisms can be obtained as truth-telling equilibrium outcomes of a revelation mechanism. Although studying revelation mechanisms is without loss of generality and it is analytically much simpler than studying other renegotiation games, the reader should be forewarned that there may be no straightforward correspondence between the actions that players take in a revelation game and the actions that they take in an actual debt workout. In Section 3 of the paper we will show how to "translate" an equilibrium of the revelation game into an equilibrium of an exchange offer.

The structure of the revelation mechanism is as follows: creditors confidentially and simultaneously report their private information (their type $x_{i}$ ) to a fictitious mediator. Based on the reports, the mediator instructs the debtor to invest (remain in business) with probability $p$, and not to invest (file for bankruptcy) with probability $(1-p)$. The mediator also recommends that, if it chooses to remain in business, the firm make certain payments to its creditors. The vector of recommended payments is $\omega \equiv$ $\left(\omega_{1}, \omega_{2}, \ldots, \omega_{n}\right)$. If the payment $\omega_{i}$ is less than the amount of scheduled debt service that creditor $i$ has a right to receive $(d)$, then creditor $i$ accepts to write down his claims. Thus, $d-\omega_{i}$ is the amount of debt forgiveness granted by creditor $i$ in the workout agreement.

In a truth-telling equilibrium of the revelation game, it must be a best response for each creditor to report his true type, and all the creditors and the debtor must be willing to follow the recommendation of the mediator. Let $\hat{x} \equiv\left(\hat{x}_{1}, \hat{x}_{2}, \ldots, \hat{x}_{n}\right)$ be the vector of reported types. Let $\omega: I_{n} \rightarrow \mathbb{R}^{n}$ be the payment vector recommended by the mediator as a function of the reported types, and let $p: I_{n} \rightarrow[0,1]$ be the probability of investment recommended by the mediator as a function of the reported types. Accordingly, if the mediator chooses a mechanism $(\omega, p)$, then $\omega_{j}\left(\hat{x}_{i}, x_{-i}\right)$ is the payment to creditor $j$ and $p\left(\hat{x}_{i}, x_{-i}\right)$ is the probability of investment when creditor $i$ reports $\hat{x}_{i}$ and all the other creditors report their true types.

In an equilibrium in which all other creditors report their true type, the expected utility to creditor $i$ from a mechanism $(\omega, p)$ is

$$
\int_{I_{n-1}}\left\{p\left(\hat{x}_{i}, x_{-i}\right) \omega_{i}\left(\hat{x}_{i}, x_{-i}\right)+\left[1-p\left(\hat{x}_{i}, x_{-i}\right)\right] l_{i}\left(x_{i}, x_{-i}\right)\right\} f\left(x_{-i}\right) d x_{-i} .
$$

Recalling the definition of $l_{i}\left(x_{i}, x_{-i}\right)$ and the properties of the revision functions, the expression above can be rewritten as

$$
x_{i}+\int_{I_{n-1}} p\left(\hat{x}_{i}, x_{-i}\right)\left[\omega_{i}\left(\hat{x}_{i}, x_{-i}\right)-l_{i}\left(x_{i}, x_{-i}\right)\right] f\left(x_{-i}\right) d x_{-i} .
$$


If no debt workout is attempted the firm goes bankrupt and creditors get their expected bankruptcy payoff $x_{i}{ }^{10}$ Thus, the change in expected utility from the mechanism $(\omega, p)$ is

$$
U\left(x_{i}, \hat{x}_{i}, \omega_{i}, p\right) \equiv \int_{I_{n-1}} p\left(\hat{x}_{i}, x_{-i}\right)\left(\omega_{i}\left(\hat{x}_{i}, x_{-i}\right)-l_{i}\left(x_{i}, x_{-i}\right)\right) f\left(x_{-i}\right) d x_{-i} .
$$

Since outside of bankruptcy debt forgiveness must be granted voluntarily, creditors must be willing to participate in the mechanism. ${ }^{11}$ For this to be the case,

$$
U\left(x_{i}, x_{i}, \omega_{i}, p\right) \geq 0
$$

for all $x_{i} \in[\underline{x}, \bar{x}]$ and all $i=1, \ldots, n$. In a truth-telling equilibrium, the debtor's expected utility from the mechanism $(\omega, p)$ is

$$
V(x, p, \omega) \equiv \int_{I_{n}} p(x)\left(C-\sum_{i=1}^{n} \omega_{i}(x)\right) f(x) d x
$$

Accordingly, the participation constraint for the debtor is

$$
V(x, p, \omega) \geq 0
$$

An alternative specification of the debtor participation constraint is discussed in Section 6 below. Finally, for truthful reporting to be an equilibrium the mechanism must satisfy the following incentive-compatibility constraints,

$$
U\left(x_{i}, x_{i}, \omega_{i}, p\right) \geq U\left(x_{i}, x_{j}, \omega_{i}, p\right)
$$

for all $x_{i}, x_{j} \in[\underline{x}, \bar{x}]$, and for all $i$ and $j$. Using standard techniques (see Myerson, 1981), it can be shown that the following are necessary and sufficient conditions for incentive-compatibility:

${ }^{10}$ This formulation implicitly assumes that creditors do not have the option of selling their claims to the other creditors or to third parties, or that such an option would not be more attractive than the option of holding on to the claims. The issue of trading opportunities is addressed in Section 4 below.

${ }^{11}$ Much of the work on public goods does not impose voluntary participation constraints on the beneficiaries of the goods, so the results are not directly applicable here (see, for instance, d'Aspremont and Gérard-Varet, 1979). 


$$
\begin{gathered}
P\left(x_{i}\right) \equiv \int_{I_{n-1}} p\left(x_{i}, x_{-i}\right) f\left(x_{-i}\right) d x_{-i} \\
\text { must be decreasing in } x_{i} \text { for all } x_{i} \in[\underline{x}, \bar{x}] ; \\
U\left(x_{i}, x_{i}, \omega_{i}, p\right)=U\left(\bar{x}, \bar{x}, \omega_{i}, p\right) \\
+\int_{I_{n-1}} \int_{x_{i}}^{\bar{x}} p\left(u, x_{-i}\right) d u f\left(x_{-i}\right) d x_{-i} \quad \text { for all } x_{i} .
\end{gathered}
$$

The first condition states that the higher the expected bankruptcy payoff of a creditor the smaller the probability, as expected by that creditor, that the firm will stay in business. This condition is quite natural, since creditors with high expected bankruptcy payoffs are less eager to see the firm continue. The second condition (derived in Appendix 1) states that the mechanism must give each creditor the expected change in utility of the highest type $\bar{x}$ plus a positive mark-up. Since $U\left(\bar{x}, \bar{x}, \omega_{i}, p\right) \geq 0$ (by (4)), it follows that an incentive-compatible renegotiation plan that satisfies the participation constraints must give creditors more than their reservation change in utility (which is zero). The mark-up on the RHS of (9) is an "informational rent" paid by the mechanism to creditors of type $x_{i}<\bar{x}$. Creditors with lower bankruptcy payoffs are more willing to provide debt forgiveness, but to induce them to reveal that information the mechanism must give them more expected utility. Thus, the mark-up is decreasing in $x_{i}$.

Consider now an incentive compatible mechanism in which $U\left(\bar{x}, \bar{x}, \omega_{i}, p\right)=0$. Among all incentive compatible mechanisms, this is the most favorable to the debtor, because creditors' utility is kept at a minimum. In the Appendix it is shown that the amount the debtor expects to pay to creditor $i$ according to such a mechanism is equal to the expected bankruptcy payoff of creditor $i$ plus an additional term, which is just a reformulation of the informational rent on the RHS of Eq. (9):

$$
\int_{I_{n}} p(x) \omega_{i}\left(x_{i}, x_{-i}\right) f(x) d x=\int_{I_{n}} p(x)\left[l_{i}\left(x_{i}, x_{-i}\right)+\frac{F\left(x_{i}\right)}{f\left(x_{i}\right)}\right] f(x) d x .
$$

Substituting in (5), the debtor's expected utility becomes

$$
\int_{I_{n}} p(x)\left(C-\sum_{i=1}^{n}\left[l_{i}\left(x_{i}, x_{-i}\right)+\frac{F\left(x_{i}\right)}{f\left(x_{i}\right)}\right]\right) f(x) d x .
$$

Proposition 1. A mechanism $(\omega, p)$ is incentive compatible and satisfies the participation constraints (4) and (6) if and only if

$$
\int_{I_{n}} p(x)\left(C-\sum_{i=1}^{n}\left[l_{i}\left(x_{i}, x_{-i}\right)+\frac{F\left(x_{i}\right)}{f\left(x_{i}\right)}\right]\right) f(x) d x \geq 0 .
$$


This result is essentially the same as Laffont and Maskin (1979), Rob (1989), and Mailath and Postlewaite (1990). Inspection of (11') shows that debt renegotiation can succeed even if there is a multiplicity of creditors, because $p(x)$ can be nonzero for some values of $x$ without violating $\left(11^{\prime}\right) \cdot{ }^{12}$ However, successful renegotiation is too rare compared with what is required by $e x$ post efficiency: if $p(x)=1$ whenever $C \geq \sum_{i=1}^{n} l_{i}\left(x_{i}, x_{-i}\right)$ and $p(x)=0$ otherwise, condition (11) is violated unless the going concern value $C$ happens to be very large. Hence, with multiple, privately informed creditors financial distress is costly, because firms with a positive going concern surplus may go bankrupt. The inefficiency arises because of asymmetric information: with full information, the debtor could propose a plan that gives each creditor his expected bankruptcy payoff $l_{i}\left(x_{i}, x_{-i}\right)$. Creditors would accept, and the debtor would invest whenever it is efficient to do so. With asymmetric information, to implement this mechanism creditors would have to report their private information truthfully, but would have no incentive to do so, as reporting a higher expected bankruptcy payoff would make them better off. To avoid this type of free riding, an incentivecompatible mechanism must be devised. As shown above, this implies that the debtor must give up rents to the creditors. Since obtaining debt forgiveness is more costly than under full information, it may not be profitable for the debtor even if the investment project is socially efficient.

Next we will show that if creditor heterogeneity is due to differences of information and not just to differences in preferences, then achieving coordination is easier, and the debtor is better off.

Proposition 2. For any incentive compatible investment rule $p(x)$, the debtor's expected profits are higher under common values than under pure private values.

\section{Proof. See Appendix 1.}

The intuition behind this result is the following. Each creditor knows that debt restructuring will succeed only if other debtholders have a low expected bankruptcy payoff. With common values, this means that the expected bankruptcy value of the firm conditional on a successful restructuring is smaller than the unconditional expected bankruptcy value. Hence, with common values, a creditor is more willing to contribute to debt forgiveness. This is the opposite of the "winners' curse" in auctions (Milgrom, 1987): in an auction with common values, obtaining the object reveals to the bidder that his estimate of the value was too high, so bidding behavior is more conservative. Proposition 2 also implies that, under common values,

${ }^{12}$ Mailath and Postlewaite (1990) show that, with pure private values, as $n \rightarrow \infty$ the probability that (8) is satisfied goes to zero, so inefficiency becomes the rule as in Gertner and Scharfstein (1991). 
condition $\left(11^{\prime}\right)$ of Proposition 1 is more likely to be satisfied for any given investment rule $p(x)$. Hence, debt restructuring is less likely to be inefficient when creditor heterogeneity is due, at least in part, to differences in information.

\section{AN INTERPRETATION OF EXCHANGE OFFERS}

In the United States, bonds are often restructured outside of bankruptcy through exchange offers. In an exchange offer, the debtor proposes to exchange existing debt for a new security with a lower interest rate or a lower face value than the old one. Sometimes the new claim is a composite of debt and other securities. Usually, the success of the offer is contingent on a minimum tendering requirement. There are two features that characterize exchange offers as a renegotiation mechanism. First, creditors choose which fraction of their holdings to exchange, effectively choosing how much to contribute to debt forgiveness. Second, the offer specifies in advance that the transaction is void unless a sufficient amount of securities are tendered. In this section, we will show that, when there is a multiplicity of privately informed creditors, it is optimal for an indebted firm to restructure its debt through an exchange offer. To show this result, we will first derive the equilibrium outcome of a revelation mechanism that maximizes the debtor's expected profits. This mechanism will be referred to as the "optimal" revelation mechanism, although it is optimal only from the point of view of the debtor. ${ }^{13}$ Because of the Revelation Principle, this mechanism yields the debtor the maximum payoff from any renegotiation mechanism. Then, we construct an exchange offer game, and show that (under some additional parameter restrictions) there exists a Bayesian-Nash equilibrium of that game in which the debtor (and the creditors) gets exactly the same payoffs as in the equilibrium of the optimal mechanism. Hence, renegotiating the debt through an exchange offer maximizes the debtor's expected profits.

\subsection{An Optimal Revelation Mechanism}

In Section 2 it was shown that the maximum expected profits that the debtor can obtain from an incentive-compatible revelation mechanism that does not violate the creditors' participation constraints are given by Eq. (11). Choosing $p(x)$ to maximize (11) pointwise,

${ }^{13}$ Because the debtor uses his monopoly power to extract rents from the creditors, the outcome of this mechanism leads to larger ex post inefficiencies than what asymmetric information alone would imply. 


$$
\hat{p}(x) \equiv \begin{cases}1 & \text { if } C \geq \sum_{i=1}^{n}\left[l_{i}\left(x_{i}, x_{-i}\right)+\frac{F\left(x_{i}\right)}{f\left(x_{i}\right)}\right] \\ 0 & \text { otherwise. }\end{cases}
$$

According to this rule, the firm should remain in business with probability one if its continuation value exceeds the sum of the payoffs that creditors expect to receive in liquidation augmented by the terms $F\left(x_{i}\right) / f\left(x_{i}\right)$. So this continuation rule resembles the investment rule that yields the efficient continuation/liquidation decision (see Section 2.1 above), but, because of the terms $F\left(x_{i}\right) / f\left(x_{i}\right)$, it results in the firm going bankrupt too often. The investment rule $\hat{p}(x)$ and the condition that $U(\bar{x}, \bar{x}, \omega, p)=0$ fully determine the expected profits of the debtor. Through (9), the expected utility of each creditor can also be computed without deriving the payment function $\omega(x)$. To prove the optimality of exchange offers in the next section, however, it is necessary to derive an explicit solution for $\omega(x)$. To this end, rewrite the investment rule $\hat{p}(x)$ as

$$
\hat{p}(x)= \begin{cases}1 & \text { if } C \geq A\left(x_{i}\right)+Q\left(x_{-i}\right) \\ 0 & \text { otherwise }\end{cases}
$$

where

$$
A\left(x_{i}\right)=x_{i}+\frac{F\left(x_{i}\right)}{f\left(x_{i}\right)}+\sum_{j \neq i} e_{j}\left(x_{i}\right)
$$

and

$$
Q\left(x_{-i}\right)=\sum_{j=1}^{n} \sum_{k \neq j, i} e_{j}\left(x_{k}\right)+\sum_{j \neq i}\left[x_{j}+\frac{F\left(x_{j}\right)}{f\left(x_{j}\right)}\right] .
$$

Following Rob (1989), let us assume that the hazard rate of $F(x)$ is monotonic:

Assumption 2. $F\left(x_{i}\right) / f\left(x_{i}\right)$ is strictly increasing for all $x_{i} \in[\underline{x}, \bar{x}]$ and all $i=1, \ldots, N$.

This property holds for several commonly used distribution functions. Under this assumption, $A\left(x_{i}\right)$ is strictly increasing (Eq. (13)). Hence, for each vector $x_{-i}$ there exists a unique value of $x_{i}$ that solves

$$
C=A\left(x_{i}\right)+Q\left(x_{-i}\right) .
$$


Let $\tilde{x} \equiv \tilde{x}\left(x_{-i}\right)$ denote this value. Given that the other creditors report $x_{-i}$, $\tilde{x}$ is the largest type that creditor $i$ can report to the mediator without forcing bankruptcy. Hence, $\tilde{x}\left(x_{-i}\right)$ is the "pivotal" type of creditor $i$ according to the investment rule $\hat{p}(x)$. Note that, if the other creditors report low types, the term $Q\left(x_{-i}\right)$ is small, and the pivotal type for creditor $i$ is large. Hence, $\widetilde{x}\left(x_{-i}\right)$ measures the extent of the opportunities for holding out (Rob, 1989).

LEMMA 1. In the optimal mechanism, the payment to creditor i is given by

$$
\hat{\omega}_{i}\left(x_{i}, x_{-i}\right)=\hat{\omega}_{i}\left(x_{-i}\right)=\tilde{x}\left(x_{-i}\right)+e_{i}\left(x_{-i}\right) .
$$

\section{Proof. See Appendix 1.}

According to Lemma 1, in the optimal mechanism creditor $i$ receives a payment that is independent of the type that he reports, and may be increasing or decreasing in the types reported by the other creditors. The function $\tilde{x}\left(x_{-i}\right)$ is decreasing in each component of $x_{-i}$, as remarked above. On the other hand, $e_{i}\left(x_{-i}\right)$ is increasing in each component of the vector $x_{-i}$, because, if other creditors report high bankruptcy payoffs, then creditor $i$ revises his expected bankruptcy payoff upward, and is less willing to contribute to debt forgiveness. If the "holding out effect" dominates the "revision of expectations" effect, then the payment from the optimal mechanism is decreasing in each component of $x_{-i}$. In the case of pure private values there is no revision of expectation effect, and $\hat{\omega}_{i}\left(x_{i}, x_{-i}\right)$ is decreasing in the type of the other creditors.

\subsection{An Exchange Offer Game}

Consider the following procedure for renegotiating the debt. The debtor offers creditors a new security with face value $b$ in exchange for their old claims (of course, in equilibrium $b<d$ ), and invites the creditors to tender. The offer states that the exchange will be valid (and the firm will remain in business) only if the amounts tendered satisfy a certain condition specified in the offer. Otherwise, the exchange will be void, the creditors' original claims will remain in force, and the debtor will file for bankruptcy. After the offer is announced, creditors simultaneously exchange a fraction $h_{i} \in$ $[0,1]$ of their holdings. Let $h \equiv\left(h_{1}, h_{2}, \ldots, h_{n}\right)$ denote the vector of amounts tendered. If the vector $h$ satisfies the condition specified in the offer, the offer is valid and the investment is undertaken. Otherwise the offer is void and the firm files for bankruptcy. Notice that no new decision is made at this stage of the game because the debtor just follows the rules stated in the offer. ${ }^{14}$

${ }^{14}$ On the issue of ex post renegotiation of the mechanism, see Section 6 below. 
This renegotiation mechanism, while it resembles an exchange offer, is not a revelation mechanism, since there is no fictitious mediator to receive reports and to recommend actions based on those reports. In the revelation game creditors choose the type that they report and whether or not to participate. In the exchange offer game the only action chosen by the creditors is the amount tendered $h_{i}$. Also, the investment rule chosen by the debtor is a function of the amounts tendered and not of the reported types as in the revelation mechanism. To show that there is an equilibrium of the exchange offer game that yields the same payoffs as the optimal revelation mechanism, it will be shown that the amounts that creditors tender in the exchange offer are monotonic functions of their type. Hence, the debtor can infer the type of each creditor by observing the amounts tendered, and he can then follow the same investment rule of the optimal revelation mechanism. To prove these results, it is necessary to impose an additional assumption on the parameter values.

Assumption 3. The parameters $\underline{x}, \bar{x}, C$, and $n$, and the functions $e_{i}\left(x_{j}\right)$, $F\left(x_{i}\right)$, and $f\left(x_{i}\right)$ are such that for all $x_{-i}$ and $x_{-i}^{\prime} \in I_{n-1}$, if $Q\left(x_{-i}\right)>Q\left(x_{-i}^{\prime}\right)$, then $\hat{\omega}_{i}\left(x_{-i}\right)<\hat{\omega}_{i}\left(x_{-i}^{\prime}\right)$ (where $Q\left(x_{-i}\right)$ is defined in (16)).

This assumption states that the payment assigned to creditor $i$ by the optimal revelation mechanism (see Lemma 1) must be smaller the "larger" the vector of other creditor types, where "larger" means to yield a larger $Q\left(x_{-i}\right)$. This assumption is satisfied if the "revision of expectation effect" on $\hat{\omega}_{i}\left(x_{i}\right.$, $\left.x_{-i}\right)$ is small relative to the "holding out effect."

Proposition 3. Under Assumptions 1-3, there is an equilibrium of the exchange offer game that yields the debtor and the creditors the same expected utility as the optimal revelation mechanism. In this equilibrium, creditors with lower expected bankruptcy payoff tender a larger fraction of their portfolios making a greater contribution to debt forgiveness.

Sketch of the Proof (see Appendix 1 for the complete proof). The first step is to derive the amount that a creditor of type $x_{i}$ must tender to obtain the same expected utility as in the equilibrium of the optimal revelation mechanism. Let $\hat{H}\left(x_{i}\right)$ denote this amount. The second step is to show that, for an appropriate choice of $b$, the face value of the new security, $\hat{H}\left(x_{i}\right) \in$ $[0,1]$ for all $x_{i} \in[\underline{x}, \bar{x}]$. The third step is to show that the functions $\hat{H}\left(x_{i}\right)$ are monotonically decreasing, i.e., that creditors who expect to receive a higher payoff in bankruptcy tender a smaller share of their portfolio, and therefore contribute less to debt forgiveness. Assumption 3 is needed for this result. Once it is established that $\hat{H}\left(x_{i}\right)$ is monotonic, the function can be inverted to yield

$$
x_{i}=H^{-1}\left(h_{i}\right) \equiv G\left(h_{i}\right)
$$


Using this relationship, the investment rule of the revelation mechanism $\hat{p}(x)$ can be expressed as a rule for the success of the exchange offer based on the amounts tendered. Accordingly, in the equilibrium of the exchange offer game the debtor announces that the exchange offer is valid if and only if the amounts tendered satisfy

$$
C \geq \sum_{i=1}^{N}\left\{l_{i}\left[G\left(h_{i}\right), G\left(h_{-i}\right)\right]+\frac{F\left[G\left(h_{i}\right)\right]}{f\left[G\left(h_{i}\right)\right]}\right\},
$$

where $h_{-i} \equiv\left(h_{1}, \ldots, h_{i-1}, h_{i+1}, \ldots, h_{n}\right)$. Since the debtor is committed to invest whenever the offer succeeds, this announcement results in the investment rule $\hat{p}(G(h))$. If creditors of type $x_{i}$ tender $H\left(x_{i}\right)$, then $\hat{p}(G(h))=\hat{p}(x)$, and in the equilibrium of the exchange offer the firm remains in business for the same realizations of the vector of types $x$ as in the equilibrium of the optimal revelation mechanism. Since the investment rule $\hat{p}(x)$ maximizes the debtor's expected profits, if creditors respond by tendering $\hat{H}(x), \hat{p}(G(h))$ is optimal for the debtor. On the other hand, given the investment rule $\hat{p}\left(G\left(h_{i}\right)\right)$, by construction tendering $\hat{H}\left(x_{i}\right)$ gives a creditor of type $x_{i}$ the same expected utility as the revelation mechanism. Deviating from $\hat{H}\left(x_{i}\right)$ means imitating the action of another type. By incentive-compatibility, this is suboptimal, and $\hat{H}\left(x_{i}\right)$ is a best response.

Exchange offers are optimal for the debtor because they allow creditors who are optimistic about the outcome of bankruptcy to contribute less to debt forgiveness, and vice versa. By exploiting the creditors' different "willingness to pay" for the benefit of staying out of bankruptcy, the debtor effectively engages in price discrimination. ${ }^{15}$

For the exchange offer to succeed, the amounts tendered must satisfy condition (18). Generally, this condition is more complex than a minimum tendering requirement, so the equilibrium of the exchange offer game of Proposition 3 does not exactly match real world exchange offers. However, condition (18) can be expressed as a minimum tendering requirement for particular parameterizations of the model. Specifically, if there exists a monotonically increasing function $R(\cdot)$ such that

$$
R\left(\sum_{i=1}^{N} h_{i}\right)=\sum_{i=1}^{N}\left\{l_{i}\left[G\left(h_{i}\right), G\left(h_{-i}\right)\right]+\frac{F\left[G\left(h_{i}\right)\right]}{f\left[G\left(h_{i}\right)\right]}\right\}
$$

15 This result is related to Cornelli (1992). She shows that, for a monopolist facing a fixed cost of production, the optimal selling procedure is to offer customers a menu of possible prices. As in our case, high valuation consumers are willing to pay a price above the minimum to increase the probability of the good being produced. 
then the exchange offer succeeds if and only if

$$
\sum_{i=1}^{N} h_{i} \geq R^{-1}(C),
$$

and $R^{-1}(C)$ is the minimum tendering requirement. The function $R(\cdot)$ exists if, for instance, the distribution function $F\left(x_{i}\right)$ is of the class $k\left(x_{i}\right)^{\alpha}$, with $\alpha$ and $k$ constant, and if the revision functions are linear.

\section{TRADING DISTRESSED DEBT}

A complete model of debt renegotiation would derive the allocation of the debt among agents with different expected bankruptcy payoff as the equilibrium allocation of a trading mechanism. In equilibrium, the allocation of the debt among investors would be such that, given the expected outcome of debt renegotiation, all market participants are unwilling to trade any further. Thus, such an allocation would depend on the specific "microstructure" of the market in which debt is traded. To illustrate the effect of introducing trading into the model, let us consider the case in which the debt consists of bonds that can be traded with a market maker. Let $\pi^{\mathrm{b}}$ and $\pi^{\mathrm{a}}$ denote the bid and ask price respectively (with $\pi^{\mathrm{b}} \leq \pi^{\mathrm{a}}$ ), prevailing at the time at which the exchange offer is announced. The literature on dealer's markets shows how equilibrium bid and ask prices depends on factors such as the cost for the dealer of holding a suboptimal portfolio (Ho and Stoll, 1981), the monopolistic power of the dealer (Amihud and Mendelson, 1980), and the cost of trading with agents with inside information (Copeland and Galai, 1983; Glosten and Milgrom, 1986). Modeling the determination of the bid and ask prices in equilibrium along the lines suggested in the literature would involve adding a considerable amount of machinery to our model and it is beyond the scope of this paper, so we will simply take $\pi^{\mathrm{b}}$ and $\pi^{\mathrm{a}}$ as exogenous. Participating in the exchange offer yields a type $x_{i}$ expected utility

$$
\begin{aligned}
Y\left(x_{i}, x_{i}, \hat{p}, \hat{\omega}\right) & =U\left(x_{i}, x_{i}, \hat{p}, \hat{\omega}\right)+\int_{I^{n-1}} l_{i}\left(x_{i}, x_{-i}\right) f\left(x_{-i}\right) d x_{-i} \\
& =U\left(x_{i}, x_{i}, \hat{p}, \hat{\omega}\right)+x_{i} .
\end{aligned}
$$

For the exchange offer to be an equilibrium with trading, it must be the case that all possible creditor types are better off participating in the exchange offer than if they trade with the dealer, because further trade would change the allocation of the claims upon which the exchange offer 
is predicated. By Eq. (A1) in Appendix 1, $d U / d x_{i}=-\int_{I^{n-1}} \hat{p}\left(x_{i}, x_{-i}\right) f\left(x_{-i}\right)$ $d x_{-i}$. Since $\hat{p} \leq 1 \forall x_{i}$ and $x_{-i}$, the function $Y\left(x_{i}, x_{i}, \hat{p}, \hat{\omega}\right)$ is increasing in the type of creditor. Thus, the expected utility from participating in the exchange offer ranges from a minimum of $Y(x, x, \hat{p}, \hat{\omega})$ to a maximum of $Y(\bar{x}, \bar{x}, \hat{p}, \hat{\omega})$. Clearly, no further trading is an equilibrium if and only if $\pi^{\mathrm{b}} \leq Y(\underline{x}, \underline{x}, \hat{p}, \hat{\omega})<Y(\bar{x}, \bar{x}, \hat{p}, \hat{\omega}) \leq \pi^{\mathrm{a}}$.

Thus, the opportunity to trade with the market maker puts bounds on the extent of creditor heterogeneity that is present when the debt is restructured. In the extreme case in which the bid-ask spread is zero, there would be no residual heterogeneity among creditors, and the secondary market price would reveal the bondholders' expected bankruptcy value. This extreme case, however, is not realistic. Secondary markets for distressed corporate bonds are usually characterized by large bid-ask spreads (Ramaswami and Moeller, 1990, Altman, 1991). Also, in the case of LDC sovereign debt in 1986-1987, James (1990) finds evidence supporting the hypothesis that creditor banks had heterogeneous valuations in spite of the existence of an informal secondary market. When bank loans or trade credits are considered, trading frictions are likely to be even more relevant since no organized secondary market exists. In this case, bilateral trading models would probably be the most accurate description of the trading mechanism. Models of bilateral trade with asymmetric information indicate that potential gains from trade are generally not exhausted (Myerson and Satterthwaite, 1983; Matsuo, 1989). The inefficiencies are even stronger in the case of common values (Vincent, 1989). Thus, the assumption that creditors of distressed firms are heterogeneous is not inconsistent with the existence of limited trading opportunities.

These observations concern the effect of introducing trading opportunities before debt is renegotiated. If debt can be traded also after restructuring takes place, $l_{i}\left(x_{i}, x_{-i}\right)$ should be reinterpreted as the maximum of two quantities, the value that creditor $i$ expects to receive in bankruptcy and the price that he expects to receive if he sells the claim. What complicates the analysis is that, in principle, the resale price may be affected by the information that is revealed during renegotiation. If creditors are aware of this effect, then their strategies in renegotiation may change. This problem is studied by Bikhchandani and Huang (1989) in reference to U.S. Treasury bills auctions. U.S. Treasury bills are auctioned off to primary dealers who resell the securities to the public at large. Bidding strategies in the primary auction, if observable to the public, reveal information that is reflected in the secondary market price. Unfortunately, incorporating this effect into our model would substantially increase the level of complexity of our problem. Since the resale market is less important for distressed debt than it is for primary dealers in Treasury bills we do not address the issue in this paper. 


\section{WAIVING THE SENIORITY COVENANT}

As an alternative to debt forgiveness, the indebted firm could ask creditors to waive the strict seniority covenant attached to existing debt contracts. ${ }^{16}$ Depending on the original contractual agreements, such a waiver may need the unanimous consent of the creditors or just a majority vote. If the seniority covenant is waived, the firm can obtain the funds to finance the project by issuing a senior loan of size $I$. Given that the senior loan would be riskless and that the riskless rate of interest is assumed to be zero, the debt service payment on the senior loan would also be $I$. Hence, after the returns are realized and senior creditors are repaid, the cash flow left to be divided among shareholders and old creditors would be $C$. Old creditors would still be entitled to the full face value of their claims $D$. Since $C$ is assumed to be nonstochastic and the firm is assumed to be insolvent $(C<D)$, when the cash flow from the project is realized each creditor would receive $C / n$ and shareholders would receive nothing. Hence, in equilibrium creditors whose expected bankruptcy payoff exceeds $C / n$ would reject the waiver and vice versa. If the waiver has to be approved unanimously, then the firm will remain in business if and only if all creditors have an expected bankruptcy payoff below $C / n$. Thus, the covenant renegotiation game with unanimous approval can be thought of as a direct revelation mechanism $(\omega, p)$ in which the investment rule $p(x)$ specifies that the firm invests with probability one if all creditors have an expected liquidation value below $C / n$ and invests with probability zero otherwise, while the payment function is $\omega_{i}(x)=C / n$ for all $i$ and $x$. Since this mechanism is individually rational and incentive-compatible,,${ }^{17}$ the result of Proposition 1 holds. Accordingly, if debt is renegotiated through a waiver of the seniority covenant the firm will file for bankruptcy too often relative to ex post efficiency. Since the shareholders of the indebted firm obtain zero profits by obtaining a covenant waiver, if the renegotiation mechanism is chosen by shareholder-oriented management exchange offers will be the preferred technique. If the cash flow is a random variable, shareholders may earn positive expected profits from the waiver if there are states of nature in which the cash flow exceeds $D+I$. Nonetheless, the direct mechanism that corresponds to covenant renegotiation generally is not a solution to the problem of maximizing (10) by choice of $p$. Hence, exchange offers are better for shareholders.

${ }^{16} \mathrm{We}$ are indebted to a referee for suggesting this point.

${ }^{17}$ To verify that the mechanism is incentive-compatible, note that if a type $x_{i} \leq C / n$ reports a type $x^{\prime}<x_{i}$ there is no effect on his expected payoff, because the probability that the firm will invest is still equal to the probability that all $n-1$ other players have liquidation values below $C / n$, and the payoff rate is unchanged. On the other hand, reporting a type $x^{\prime}<C / n$ stops the firm from investing altogether, which makes creditor $x_{i}$ worse off. Similar reasoning holds for types $x_{i}>C / n$. 
On the other hand, if the covenant can be waived through a majority vote, then this renegotiation procedure no longer belongs to the class of mechanisms studied so far because the participation constraints of the creditors need not hold with probability one. In this case, in contrast with the result of Proposition 1, the firm may invest too often relative to ex post efficiency. An example in Appendix 2 illustrates this result. If the cash flow is nonstochastic, the shareholders of the indebted firm earn zero profits with covenant renegotiation and they are strictly better off using an exchange offer even if the covenant can be waived by a majority vote. On the other hand, if the cash flow from the project is random, depending on the parameters shareholders may be better off using covenant renegotiation. Exchange offers have the advantage that they allow shareholders to obtain explicit debt forgiveness and to "price discriminate" among the creditors, but the need to obtain unanimous approval may offset such advantages and make covenant renegotiation a better option. An example in Appendix 2 illustrates this trade-off.

\section{EXTENSIONS AND OPEN ISSUES}

\subsection{Debtor's Private Information about the Bankruptcy Value of the Firm}

The debtor may also receive private information (let's call it $x_{0}$ ) about the value of the firm in bankruptcy. In this case, the analysis of Section 2 should be modified by extending the vector of types $x$ to include also $x_{0}$, and by imposing an additional incentive-compatibility constraint in the revelation game. However, since the debtor's payoff is identically zero in bankruptcy, his expected payoff does not depend on $x_{0}$ directly, and for incentive-compatibility to hold the functions $\omega$ and $p$ must be constant in $x_{0}$ : because the debtor's expected profits are not a function of the bankruptcy value of the firm, the private information that the debtor may have concerning that value cannot be credibly communicated. This is true even if the debtor has better information than the creditors, or if he knows the true bankruptcy value of the firm. Hence, neglecting the debtor's information is without loss of generality. On the other hand, if the debtor's private information is about the going concern value of the firm, then this conclusion no longer holds, as we discuss below.

\subsection{Asymmetric Information about the Continuation Value of the Firm}

In the model presented here, the value of the firm as a going concern is known to all parties, while creditors have private information as to the value that they expect to receive in bankruptcy. Alternatively, it could be 
assumed that the going concern value of the firm is private information. In this case the renegotiation problem would change as follows. First, the type of security offered in the exchange offer (cash, risky debt, a mix of debt and equity) would dictate how creditors' expected utility depends on creditors' private information. For instance, creditors' expected payoff is independent of the going concern value of the firm if the security is riskless debt, but it is linear in the estimated going concern value if the security is equity. Second, the debtor's expected profits would be a function of the going concern value, so the debtor's private information would become important. The choice of the restructuring plan (including the choice of security) would reveal some of the debtor's private information.

Information revelation through the choice of the new security in debt workouts has been studied in models in which the debtor knows the true continuation value of the firm and creditors behave like a coalition. ${ }^{18}$ However, the general case, in which all parties have potentially relevant private information and there are coordination failures among creditors, remains to be investigated.

\subsection{Ex Ante versus Ex Post Budget Balance}

In the literature on public goods, the participation constraint imposed on the debtor (Eq. (6)) is often referred to as "ex ante budget balance." This constraint requires the mechanism to make the debtor better off $e x$ ante, i.e., before the debtor knows the payments that he will have to make to the creditors. An alternative form of the participation constraint is " $e x$ post budget balance." In this case, the continuation value of the firm must exceed the total amount paid out to creditors whenever the mechanism requires the firm to stay in business with positive probability:

$$
p(x)\left[C-\sum_{i=1}^{n} \omega_{i}(x)\right] \geq 0 \quad \forall x \in I_{n} .
$$

Which of the constraints is the most appropriate depends on how the financing for the new investment project is arranged. If no financing arrangement is made before debt renegotiation takes place, then for realizations of $x$ such that $C<\sum_{i=1}^{n} \omega_{i}(x)$ no investor would be willing to finance the new project, and ex post budget balance would be a more appropriate constraint.

Alternatively, financing for the new project may be arranged before renegotiation. The debtor may have obtained a commitment by a lender

${ }^{18}$ See Brown et al. (1994) for an empirical study of information revelation through choice of security, and Detragiache (1995) for a theoretical study of how the ability to choose the mix of securities affects renegotiation efficiency. 
to finance the project conditional on the success of debt renegotiation. Prearranged financing of this type is commonly used by firms that restructure debt through exchange offers. In this case, ex ante budget balance is the appropriate constraint because, whenever ex ante budget balance holds, a risk-neutral investor should be willing to supply prearranged financing. In any case, the distinction between the two types of constraint is not very important for the results: since agents are risk-neutral and there is a continuum of possible types, for any mechanism that satisfies the creditors' participation constraints and incentive-compatibility constraints there exists a payment scheme that preserves ex post budget balance whenever ex ante budget balance holds (see Mailath and Postlewaite, 1990).

\subsection{Renegotiation with Majority Voting}

In the analysis it is assumed that debt can be restructured only with the unanimous approval of all creditors. In terms of the model, the participation constraints of all creditors have to be satisfied with probability one. Sometimes, however, a restructuring plan may be subject to majority voting. In the United States, for instance, if a firm is in Chapter 11 a restructuring plan can be approved by just a $\frac{2}{3}$ majority of each class of claimants. We claim that also under majority voting exchange offers remain useful as tools for price discrimination. Consider the following two-part mechanism: the debtor proposes a plan that includes a flat minimum debt forgiveness rate, as well as an offer to exchange the old debt for another asset with an even lower face value. Creditors vote on the plan. If the majority is in favor, all debt is scaled down, and the exchange offer takes place. If the minimum tendering requirement is met, then the firm continues, otherwise bankruptcy follows. This mechanism certainly allows shareholders to replicate the outcome of a plan that gives all debtholders the same payoff rate: it is sufficient to set the flat rate of debt forgiveness high enough to ensure that continuation is profitable even if nobody participates to the exchange offer. On the other hand, shareholders may grant themselves a higher expected profit by asking for a lower flat rate (thereby increasing the probability that the plan will be approved), and extracting further debt forgiveness from low bankruptcy value creditors through the exchange offer. As in the model of Section 3.2, some types of creditor should be willing to contribute more than the flat rate to increase the probability that the firm will remain in business.

\subsection{Renegotiation of the Mechanism Ex Post}

Depending on the particular mechanism, the ex post inefficiencies highlighted in Section 2 may create incentives to renegotiate the outcome of the game; if renegotiation is anticipated, then the nature of the equilibrium 
may change dramatically (see Myerson, 1991, Chap. 10). This is a wellknown problem in the static mechanism design literature. Ausubel and Deneckere $(1989,1993)$ showed that, in the case of bilateral trading problems, the solution to the static mechanism design problem can be sustained as a sequential equilibrium of a multiperiod game. If arguments similar to those of Ausubel and Deneckere can be extended also to mechanism design problems with many agents, then our results are valid. This is an important topic for future research.

\section{CONCLUDING REMARKS}

The analogy between debt forgiveness and the private provision of a public good indicates that, with an arbitrary number of privately informed creditors, the free-rider problem causes out-of-court debt restructuring to succeed only if efficiency gains are large enough. In general, firms are likely to go bankrupt too often for ex post efficiency to obtain, and so financial distress is costly.

An important question is whether inefficiencies of this type justify the existence of bankruptcy statutes which, by weakening the prebankruptcy rights of creditors, make restructuring more likely (such as Chapter 11 in the United States). This question is quite complex. For instance, ex ante firms may be better off when they have the option of issuing a security that is hard to renegotiate ex post, as in the models of Rajan (1992) and Detragiache (1994). Also, court intervention generates deadweight costs of its own, and it is not clear whether the party who makes the filing decision will make the socially efficient choice between liquidation and reorganization. Critics of Chapter 11 often point out that managers of distressed firms always file for reorganization, in the hope that a "miracle" will restore the firm to solvency before a final decision is made (see, for instance, Bradley and Rosenzweig, 1992). Such perverse incentives may be reduced by improving the design of reorganization laws, but they may be hard to eliminate altogether.

Our analysis also shows that, under some conditions, exchange offers are an optimal way to renegotiate debt for a firm facing a multiplicity of creditors whose willingness to contribute to debt forgiveness is private information. In an exchange offer, by choosing which fraction of the portfolio to tender, creditors choose how much debt forgiveness to supply. This helps to reduce the impact of the free rider problem. We find that exchange offers could benefit the debtor also when debt is renegotiated through a majority vote, as is the case in Chapter 11.

Since creditor heterogeneity is a barrier to efficient debt renegotiation, and trade among creditors should reduce heterogeneity, the growth of 
increasingly liquid secondary markets for distressed securities should make financial distress less costly. While in Europe no such market has yet emerged (The Economist, 1994), in the United States an informal market for nonperforming LDC loans has existed since 1986, and the market for distressed corporate bonds has grown in recent years (Altman, 1993). Specialized intermediaries (the so-called "vulture funds") buying large quantities of a distressed issue have emerged. By reducing the number of creditors involved in restructuring, vulture funds can facilitate out-of-court debt restructuring.

Related to debt renegotiation is the issue of covenant renegotiation. Berlin and Mester (1992) suggest that private debt usually carries more stringent covenants than public debt because covenant renegotiation is easier when it involves only a small number of creditors. Although we have not studied the issue of an optimal mechanism to renegotiate covenants, our results suggest that if a mechanism could be devised to give heterogeneous creditors different payoffs, then renegotiating covenants with multiple creditors would be easier, and perhaps it would become possible to attach more restrictive covenants to public debt as well. To focus on the free rider problem among creditors, our model has abstracted from several important features of real world debt restructuring. For instance, we have assumed that all debt is homogeneous, while in practice firms issue several classes of debt claims (bank debt, senior bonds, subordinated bonds, commercial paper). Different categories of creditors may also have different information. For instance, banks who have a long-term relationship with the debtor are likely to be better informed than public creditors, and in fact, banks appear to play a special role in debt restructuring. Brown et al. (1993) find that when senior bank lenders take equity as part of a restructuring plan, positive information about the firm is revealed to the market. In the same vein, James (1993) finds that the better the investment opportunities of the distressed firm, the more likely are senior banks to exchange debt for equity. This study also finds that banks tend to take equity when private creditors hold a larger share of the distressed firm's liabilities. Another issue that we have neglected is the possibility of partial liquidation. Distressed firms frequently engage in asset sales (Asquith et al., 1994). Brown et al. (1994) present evidence that asset sales by distressed firms reflect pressure from short-term creditors, and that, in contrast with asset sales by healthy firms, they benefit creditors and hurt shareholders. Finally, debt restructuring can also lead to a reallocation of control powers within the firm (Gilson, 1990). In this case the resolution of financial distress has potential effects on agency problems between management and shareholders, and the going concern value of the firm depends on how control rights are redistributed in the workout. A complete theory of financial distress will need to encompass all these aspects. Empirical studies of debt workouts 
and bankruptcy, which have grown dramatically in recent years, will certainly provide important insights for the development of such a theory.

\section{APPENDIX 1}

Derivation of Eq. (8). For the incentive-compatibility constraints to hold, it must be

$$
x_{i}=\underset{\hat{x}_{\mathrm{i}}}{\operatorname{argmax}} U\left(x_{i}, \hat{x}_{i}, \omega_{i}, p\right)
$$

Let $\hat{U}\left(x_{i}, x_{i}, p, \omega\right)$ be the maximum utility of creditor $i$ from the mechanism $(p, \omega)$. Then, by the envelope theorem

$$
\frac{d \hat{U}}{d x_{i}}=-\int_{I_{n-1}} p\left(x_{i}, x_{-i}\right) f\left(x_{-i}\right) d x_{-i} \leq 0 .
$$

Hence, the equilibrium utility from the mechanism must be decreasing in the creditor type. Reintegrating this expression,

$$
\begin{aligned}
\hat{U}\left(x_{i}, x_{i}, p, \omega\right) & =U(\bar{x}, \bar{x}, \omega, p)+\int_{I_{n-1}}\left(\int_{x_{i}}^{\bar{x}} \frac{d \hat{U}}{d u} d u\right) f\left(x_{-i}\right) d x_{-i} \\
& =U(\bar{x}, \bar{x}, \omega, p)+\int_{I_{n-1}} \int_{x_{i}}^{\bar{x}} p\left(u, x_{-i}\right) d u f\left(x_{-i}\right) d x_{-i} .
\end{aligned}
$$

Derivation of Eq. (10). From (3) and (9)

$$
\begin{aligned}
\int_{I_{n-1}} p\left(x_{i}, x_{-i}\right) \omega_{i}\left(x_{i}, x_{-i}\right) f\left(x_{-i}\right) d x_{-i}= & \int_{I_{n-1}} p\left(x_{i}, x_{-i}\right) l_{i}\left(x_{i}, x_{-i}\right) f\left(x_{-i}\right) d x_{-i} \\
& +\int_{I_{n-1}} \int_{x_{i}}^{\bar{x}} p\left(u, x_{-i}\right) d u f\left(x_{-i}\right) d x_{-i} .
\end{aligned}
$$

The second term on the RHS of this equation is the informational rent earned by creditor $i$. Taking expectations over all possible values of $x_{i}$,

$$
\begin{aligned}
\int_{I_{n}} p(x) \omega_{i}\left(x_{i}, x_{-i}\right) f(x) d x= & \int_{I_{n}} p\left(x_{i}, x_{-i}\right) l_{i}\left(x_{i}, x_{-i}\right) f(x) d x \\
& +\int_{I_{n-1}}\left[\int_{\underline{x}}^{\bar{x}} \int_{x_{i}}^{\bar{x}} p\left(u, x_{-i}\right) d u f\left(x_{i}\right) d x_{i}\right] f\left(x_{-i}\right) d x_{-i} .
\end{aligned}
$$


Integrating by parts the term in brackets,

$$
\int_{\underline{x}}^{\bar{x}} \int_{x_{i}}^{\bar{x}} p\left(u, x_{-i}\right) d u f\left(x_{i}\right) d x_{i}=\int_{\underline{x}}^{\bar{x}} p\left(x_{i}, x_{-i}\right) F\left(x_{i}\right) d x_{i} .
$$

So the expected informational rent can be written as

$$
\int_{I_{n}} p\left(x_{i}, x_{-i}\right)\left[F\left(x_{i}\right) / f\left(x_{i}\right)\right] f(x) d x
$$

Substituting in (A2) yields (10).

Proof of Proposition 2. If $p(x)$ is incentive-compatible, the debtor's expected profits are given by Eq. (10). Under pure private values, the revision functions $e_{i}\left(x_{-i}\right)$ are identically zero, so it is sufficient to show that

$$
\int_{I_{n}} p(x)\left[\sum_{i=1}^{n} e_{i}\left(x_{-i}\right)\right] f(x) d x<0 .
$$

Using the definitions of $e_{i}\left(x_{-i}\right)$ and of $P\left(x_{i}\right)$, this inequality can be rewritten as

$$
\sum_{i=1}^{n} \sum_{j \neq i}\left[\int_{\underline{x}}^{\bar{x}} P\left(x_{j}\right) e_{i}\left(x_{j}\right) f\left(x_{j}\right) d x_{j}\right]<0 .
$$

Since by definition $\int_{\underline{x}}^{\bar{x}} e_{i}\left(x_{j}\right) f\left(x_{j}\right) d x_{j}=0$ for all $i$ and $j$, and $e_{i}\left(x_{j}\right)$ is increasing, there exists an $\hat{x}_{i}$ such that $e_{i}\left(x_{j}\right) \lessgtr 0$ as $x_{j} \lessgtr \hat{x}_{i}$, and we can write

$$
\int_{\underline{x}}^{\hat{x}_{i}} P\left(\hat{x}_{i}\right) e_{i}\left(x_{j}\right) f\left(x_{j}\right) d x_{j}+\int_{\hat{x}_{i}}^{\bar{x}} P\left(\hat{x}_{i}\right) e_{i}\left(x_{j}\right) f\left(x_{j}\right) d x_{j}=0 .
$$

$P\left(x_{j}\right)$ is decreasing because of incentive-compatibility, hence

$$
\int_{\underline{x}}^{\hat{x}_{i}} P\left(x_{i}\right) e_{i}\left(x_{j}\right) f\left(x_{j}\right) d x_{j}<\int_{\underline{x}}^{x_{i}} P\left(\hat{x}_{i}\right) e_{i}\left(x_{j}\right) f\left(x_{j}\right) d x_{j},
$$

and

$$
\int_{\hat{x}_{i}}^{\bar{x}} P\left(\hat{x}_{i}\right) e_{i}\left(x_{j}\right) f\left(x_{j}\right) d x_{j}>\int_{\hat{x}_{i}}^{\bar{x}} P\left(x_{i}\right) e_{i}\left(x_{j}\right) f\left(x_{j}\right) d x_{j} .
$$


But then

$$
\int_{\underline{x}}^{\bar{x}} P\left(x_{j}\right) e_{i}\left(x_{j}\right) f\left(x_{j}\right) d x_{j}<P\left(\hat{x}_{i}\right) \int_{\underline{x}}^{\bar{x}} e_{i}\left(x_{j}\right) f\left(x_{j}\right) d x_{j}=0 .
$$

Proof of Lemma 1. From the definition of $\tilde{x}\left(x_{-i}\right)$ it follows that the investment rule of the optimal mechanism can be rewritten as

$$
p(x)=\left\{\begin{array}{lc}
1 & \text { for } x_{i} \leq \tilde{x}\left(x_{-i}\right) \\
0 & \text { otherwise }
\end{array}\right.
$$

Hence, from Eq. (7) the change in utility to creditor $i$ from the optimal mechanism is

$$
\begin{aligned}
U\left(x_{i}, x_{i}, \hat{p}, \hat{\omega}\right) & =\int_{I_{n-1}} \int_{x_{i}}^{\bar{x}} \hat{p}\left(u, x_{-i}\right) d u f\left(x_{-i}\right) d x_{-i} \\
& =\int_{I_{n-1}} \max \left[\tilde{x}\left(x_{-i}\right)-x_{i}, 0\right] f\left(x_{-i}\right) d x_{-i} .
\end{aligned}
$$

From Eqs. (A3) and (3),

$$
\begin{aligned}
\int_{I_{n-1}} \hat{p}\left(x_{i}, x_{-i}\right) \omega_{i}\left(x_{i}, x_{-i}\right) f\left(x_{-i}\right) d x_{-i} \\
\quad=\int_{I_{n-1}}\left(x_{i}+e_{i}\left(x_{-i}\right)+\max \left[\tilde{x}\left(x_{-i}\right)-x_{i}, 0\right]\right) f\left(x_{-i}\right) d x_{-i} .
\end{aligned}
$$

Since $\tilde{x}\left(x_{-i}\right)-x_{i}<0$ when $\hat{p}\left(x_{i}, x_{-i}\right)=0$, and $\tilde{x}\left(x_{-i}\right)-x_{i}>0$ when $\hat{p}\left(x_{i}, x_{-i}\right)=1$, a solution to (A4) is

$$
\hat{\omega}_{i}\left(x_{i}, x_{-i}\right)=\tilde{x}\left(x_{-i}\right)+e_{i}\left(x_{-i}\right) .
$$

Proof of Proposition 3. Define the set $\Gamma\left(x_{i}\right) \equiv\left\{x_{-i} \mid C \geq A\left(x_{i}\right)+Q\left(x_{-i}\right)\right\}$. This set contains all the vectors $x_{-i}$ such that $\hat{p}\left(x_{i}, x_{-i}\right)=1$. If $x_{i}$ is large, then the set $\Gamma\left(x_{i}\right)$ may be empty, but to keep the exposition simple this possibility is neglected in the rest of the proof. The proof for the general case is in the working paper version of this article. Let $f\left(x_{-i} \mid \Gamma\left(x_{i}\right)\right)$ denote the density of $x_{-i}$ conditional on $x_{i} \in \Gamma\left(x_{i}\right)$. If the exchange offer is expected to succeed with probability $\hat{p}(x)$, then the expected change in utility to creditor $i$ from tendering an amount $h_{i}$ is 


$$
U\left(x_{i}, h_{i}, p\right)=\int_{I_{n-1}} \hat{p}\left(x_{i}, x_{-i}\right)\left[h_{i} b+\left(1-h_{i}\right) d-l_{i}\left(x_{i}, x_{-i}\right)\right] f\left(x_{-i}\right) d x_{-i} .
$$

For the exchange offer to yield the same change in expected utility as the revelation mechanism, the amount tendered $h_{i}$ must satisfy

$$
\int_{I_{n-1}} \hat{p}\left(x_{i}, x_{-i}\right)\left[h_{i} b+\left(1-h_{i}\right) d\right] f\left(x_{-i}\right) d x_{-i}=\int_{I_{n-1}} p\left(x_{i}, x_{-i}\right) \hat{\omega}\left(x_{-i}\right) f\left(x_{-i}\right) d x_{-i},
$$

hence

$$
\left[h_{i} b+\left(1-h_{i}\right) d\right]=\int_{\Gamma\left(x_{i}\right)} \hat{\omega}_{i}\left(x_{-i}\right) f\left(x_{-i} \mid \Gamma\left(x_{i}\right)\right) d x_{-i} \equiv W\left(x_{i}\right) .
$$

Lemma 3. Under Assumptions 1-3 W( $\left.x_{i}\right)$ is strictly increasing.

Proof. As $x_{i}$ increases, the set $\Gamma\left(x_{i}\right)$ loses some elements. Specifically, only smaller vectors $x_{-i}\left(\right.$ vectors $x_{-i}$ that yield a small $\left.Q\left(x_{-i}\right)\right)$ remain in the set. By Assumption 3, the payments $\hat{\omega}_{i}$ associated with these vectors are larger, so $W\left(x_{i}\right)$ is increasing. For a creditor $i$ of type $x_{i}$ to obtain the same expected utility as in the revelation game, in the exchange offer he must tender

$$
H\left(x_{i}\right)=\frac{d-W\left(x_{i}\right)}{d-b}
$$

Since $W\left(x_{i}\right)$ is monotonically increasing by Lemma $3, H\left(x_{i}\right)$ is monotonically decreasing: creditors with a large expected bankruptcy payoff exchange a smaller fraction of their portfolio. For $H\left(x_{i}\right)$ to be feasible, it must be the case that $H\left(x_{i}\right) \in[0,1]$ for all $x_{i} \in[\underline{x}, \bar{x}]$. From (A6) this is equivalent to $W\left(x_{i}\right) \in[b, d]$ for all $x_{i} \in[\underline{x}, \bar{x}]$. Since $W\left(x_{i}\right)$ is increasing, to ensure that $W\left(x_{i}\right) \geq b$ it is sufficient that the fact value of the new asset be $b=W(\underline{x})$. To see that $W\left(x_{i}\right) \leq d$, recall that in the optimal revelation mechanism the utility of the highest bankruptcy payoff type is equal to zero, and hence

$$
\left.\int_{I_{n-1}} p\left(\bar{x}, x_{-i}\right) \hat{\omega}\left(x_{-i}\right) f\left(x_{-i}\right) d x_{-i}=\int_{I_{n-1}} \hat{p}\left(\bar{x}, x_{-i}\right) l_{i}\left(\bar{x}, x_{-i}\right)\right] f\left(x_{-i}\right) d x_{-i}
$$

Hence,

$$
W(\bar{x})=\int_{\Gamma(\bar{x})} l_{i}\left(\bar{x}, x_{-i}\right) f\left(x_{-i} \mid \Gamma\left(x_{i}\right)\right) d x_{-i} .
$$


Since $l_{i}\left(\bar{x}, x_{-i}\right) \leq d$ by Assumption 1 , it follows that also $W(\bar{x}) \leq d$. Hence, if $b=W(x)$, then $H\left(x_{i}\right) \in[0,1]$.

Since $\left.\overline{H(} x_{i}\right)$ is monotonic, it can be inverted, and for all $x_{i} \in[\underline{x}, \bar{x}]$ one can write

$$
x_{i}=H^{-1}\left(x_{i}\right) \equiv G\left(h_{i}\right)
$$

Consider the following strategy for the debtor: offer a new asset with face value $b=W(\underline{x})$, and announce that the exchange offer will succeed if and only if the amounts tendered satisfy the following condition

$$
C \geq \sum_{i=1}^{n}\left\{l_{i}\left[G\left(h_{i}\right), G\left(h_{-i}\right)\right]+\frac{F\left[G\left(h_{i}\right)\right]}{f\left[G\left(h_{i}\right)\right]}\right\} .
$$

The announced rule for the success of the exchange offer yields the same probability of investment as the optimal revelation mechanism whenever creditors tender $H\left(x_{i}\right)$. By the incentive-compatibility of the revelation mechanism, it is a best response for creditors with bankruptcy payoff $x_{i}$ to tender $H\left(x_{i}\right)$. Finally, the debtor's strategy maximizes his expected profit by construction.

\section{APPENDIX 2}

Renegotiating the Seniority Covenant: An Example

Let $n=2, x_{i} \in[0,1], F\left(x_{i}\right)=x_{i}, e_{i}\left(x_{-i}\right)=0$. In this case, $F\left(x_{i}\right) / x_{i}=x_{i}$ and the investment rule according to the optimal mechanism is $p\left(x_{1}, x_{2}\right)=1$ if $C \geq 2\left(x_{1}+x_{2}\right)$ and $p\left(x_{1}, x_{2}\right)=0$ otherwise. From (11), the expected profits of shareholders are

$$
\int_{0}^{C / 2} \int_{0}^{C / 2-x_{1}}\left[C-2\left(x_{1}+x_{2}\right)\right] d x_{2} d x_{1}=\frac{C^{3}}{24} .
$$

Note that the probability that the firm will be reorganized is $\int_{0}^{C / 2} \int_{0}^{C / 2-x_{1}}$ $d x_{2} d x_{1}=C^{2} / 8$. Suppose now that the second period cash flow is the realization of a random variable that takes the value of $C+I+\varepsilon$ with probability $\frac{1}{2}$ and the value $C+I-\varepsilon$ with the same probability. The expected value of the project net of new investment is still $C$, and $C<D$ so the firm is insolvent. The cash flow is uncorrelated with the realization of the creditor type. In this case, the expected profits of shareholders with the optimal mechanism are still given by (A8). Suppose that the seniority 
covenant attached to the initial loan can be waived if at least one of the two creditors agrees. Since $C<D$, also $C-\varepsilon<D$, hence, if the covenant is waived and the cash flow is low, each creditor receives a payoff of ( $C-$ $\varepsilon) / 2$, while shareholders of the indebted firm get nothing. In the good state, on the other hand, the payoff to each creditor is $\min [(C+\varepsilon) / 2, D / 2]$. Assuming that $D<C+\varepsilon$, in the good state each creditor receives $D / 2$ and shareholders receive $C+\varepsilon-D>0$. Then, a creditor with expected bankruptcy payoff of $x_{i}$ will approve the waiver if

$$
x_{i}<\frac{C-\varepsilon+D}{2}
$$

and the probability that the waiver is approved is

$$
\left[\frac{C-\varepsilon+D}{2}\right]\left[2-\frac{C-\varepsilon+D}{2}\right] \text {. }
$$

The expected profits of shareholders from asking for the waiver are

$$
(C+\varepsilon-D)\left(\frac{1}{2}\right)\left[\frac{C-\varepsilon+D}{2}\right]\left[2-\frac{C-\varepsilon+D}{2}\right] .
$$

For values of $\varepsilon$ close to $D-C$ the expression above is close to zero, and expected profits are larger with the exchange offer. On the other hand, if $\varepsilon$ is large the covenant waiver becomes more attractive. Note also that for ex post efficiency it must be $x_{1}+x_{2}<C$. So whenever $x_{1} \leq(C-\varepsilon+$ $D) / 2$ and $x_{2}>(C+\varepsilon-D) / 2$ renegotiation of the covenant leads to excessive investment.

\section{REFERENCES}

Alderson, M., And Betker B. (1995). Liquidation vs. continuation: Did reorganized firms do the right thing?, mimeo, Ohio State University.

Aminud, Y., And Mendelson, H. (1980). Dealership market: Market-making with Inventory, J. Finan. Econ. 8, 31-33.

Altman, E. (1991). Investing in distressed securities, in "Workouts and Turnarounds" (D. Di Napoli, S. Sigoloff, and R. Cushmann, Eds.). Irwin, New York.

Altman, E. (1993). "Corporate Financial Distress and Bankruptcy," 2nd ed. Wiley, New York. Asquith, P., Gertner R., and Scharfstein, D. (1994). Anatomy of financial distress: An examination of junk-bonds issuers, Quart. J. Econ 109, 625-658.

Ausubel, L., And Deneckere, R. (1989). A direct mechanism characterization of sequential bargaining with one-sided incomplete information, J. Econ. Theory 48, 18-46. 
Ausubel, L., And Deneckere, R. (1993). Efficient sequential bargaining, Rev. Econ. Stud. 60, 435-455.

Bagnoli, M., And Lipman, B. L. (1988). Successful takeovers without exclusion, Rev. Finan. Stud. 1, 89-110.

Berlin, M., And Mester, L. J. (1992). Debt covenants and renegotiation, J. Finan. Intermed. 2, 95-133.

Bikhchandani, S., And Huang, C. (1989). Auctions with resale markets: An exploratory model of Treasury bill markets, Rev. Finan. Stud. 2, 311-339.

Bolton, P., And Scharfstein, D. (1995). Optimal debt structure and the number of creditors, J. Polit. Econ. 104, 1-25.

Bradley, M., and Rosenzweig, M. (1992). The untenable case for Chapter 11, Yale Law Rev. 101, 1043-1095.

Brown, D., James, C., And Mooradian, R. (1993). The information content of distressed restructurings involving public and private debt claims, J. Finan. Econ. 33, 93-118.

Brown, D., JAMEs, C., AND MoOradian, R. (1994). Asset sales by financially distressed firms, J. Corporate Finan. 1, 233-258.

Bulow, J., And Shoven, J. (1978). The bankruptcy decision, Bell J. Econ. 9, 437-456.

Copeland, T., And Galai, D. (1983). Information effects on the bid-ask spread, J. Finance 38, 1457-1469.

Cornelli, F. (1992). Optimal selling procedures with fixed costs, mimeo, Harvard University.

Crémer, J., AND MCLeAn, R. (1988). Full extraction of the surplus in Bayesian and dominant strategy auctions, Econometrica 56, 1247-1258.

D'Aspremont, C., And Gérard-VAret, L. A. (1979). Incentives and incomplete information, J. Public Econ. 11, 25-45.

Detragiache, E. (1994). Public versus private borrowing: A theory with implications for bankruptcy reform, J. Finan. Intermed. 3, 327-354.

Detragiache, E. (1995). Adverse selection and the costs of financial distress, J. Corporate Finan. 1, 347-365.

The Economist (1994). Over here and over-hyped, February 12.

Gertner, R., AND SCHARFstein, D. (1991). A theory of workouts and the effects of reorganization law, J. Finance 46, 1189-1222.

Giammarino, R. (1989). The resolution of financial distress, Rev. Finan. Stud. 2, 25-47.

Gilson, S. C. (1990). Bankruptcy, boards, banks and blockholders, J. Finan. Econ. 26, 241-262.

Gilson, S. C., John, K., And Lang, L. (1990). Troubled debt restructurings, J. Finan. Econ. 27, 315-353.

Glosten, L., And Milgrom, P. (1986). Bid, ask and transaction prices in a specialist market with heterogeneously informed traders, J. Finan. Econ. 14, 71-100.

Hart, O., And Moore, J. (1995). Debt and seniority: An analysis of the role of hard claims in constraining management, Am. Econ. Rev. 85, 567-585.

Haugen, R. And Senbet, L., (1978). The insignificance of bankruptcy costs to the theory of the optimal capital structure, J. Finance 70, 383-393.

Ho, T., And Stall, H. (1981). Optimal dealer pricing under transactions and return uncertainty, J. Finan. Econ. 9, 47-73.

JACKSON, T. (1986). "The Logic and Limits of Bankruptcy Law.” Harvard Univ. Press, Cambridge.

James, Christopher M., (1990). Heterogeneous creditors and the market value of bank LDC loan portfolio, J. Monet. Econ 25, 325-346. 
JAMES, C. M. (1993). When banks take equity: An analysis of the agency costs of debt in financial distress, mimeo, University of Florida, Gainsville, FL.

LAFFOnT, J.-J., AND MASKIN, E. (1979). A differential approach to expected utility maximizing mechanisms, in "Aggregation and Revelation of Preference" (J.-J. Laffont, Ed.). North Holland, Amsterdam.

Mailath, G., and Postlewaite, A. (1990). Asymmetric information bargaining problems with many agents, Rev. Econ. Stud. 57, 351-368.

Matsuo, T. (1989). On incentive-compatible, individually rational, and ex-post efficient mechanisms for bilateral trading, J. Econ. Theory 49, 189-194.

Milgrom, P. (1987). Auction theory, in "Advances in Economic Theory, Fifth World Congress" (T. Bewley Ed.). Cambridge Univ. Press, Cambridge.

Mrtchell, J. (1990). Managerial discipline, productivity, and bankruptcy in capitalist and socialist economies, Comp. Econ. Stud. 22, 93-197.

Myers, S. (1977). Determinants of corporate borrowing, J. Finan. Econ. 5, 147-176.

Myerson, R. (1981). Optimal auction design, Math. Operat. Res. 6, 58-73.

Myerson, R. (1991). “Game Theory.” Harvard Univ. Press, Cambridge.

Myerson, R., And Satterthwaite, M. (1983). Efficient mechanisms for bilateral trading, $J$. Econ. Theory 28, 265-281.

RAJAN, R. (1992). Insiders and outsiders: the choice between informed and arm's-length debt, J. Finance 47, 1367-1400.

Ramaswami, M., and Moeller, S. (1990). "Investing in Financially Distressed Firms." Quorom Books, New York.

Roв, R. (1989). Pollution claim settlements under private information, J. Econ. Theory 47, 307-333.

VincEnt, D. (1989). Bargaining with common values, J. Econ. Theory 48, 47-62.

WeBb, D. (1987). The importance of incomplete information in explaining the existence of costly bankruptcy, Economica 54, 279-288.

WeBb, D. (1991). An economic evaluation of insolvency procedures in the United Kingdom: Does the 1986 insolvency act satisfy the creditors' bargain?, Oxford Econ. Papers 43, 139-157.

WEISs, L. A. (1990). Bankruptcy resolution. Direct costs and violation of priority of claims, J. Finan. Econ. 27, 285-314.

White, M. (1980). Public policy towards bankruptcy: Me-first and other priority rules, Bell J. Econ. 27, 285-314.

White, M. (1980). The corporate bankruptcy decision, J. Econ. Perspect. 3, 129-151. 